\title{
STRES DAN KOPING PEREMPUAN HAMIL YANG DIDIAGNOSIS HIV/AIDS DI DKI JAKARTA: STUDI GROUNDED THEORY
}

\author{
Yulia Irvani Dewi*, Setyowati**, Yati Afiyanti**
}

\begin{abstract}
Abstrak
Penelitian ini adalah penelitian kualitatif dengan menggunakan pendekatan grounded theory yang bertujuan mengidentifikasi stres dan koping perempuan hamil yang didiagnosis HIV/AIDS. Jumlah partisipan sebanyak enam orang. Pengumpulan data dengan teknik observasi, wawancara mendalam, dan telaah literatur. Hasil analisis didapatkan tujuh tema yaitu 1) khawatir terhadap keselamatan janin, 2) diperlakukan berbeda dari perempuan hamil lainnya, 3) banyak membutuhkan biaya pengobatan, 4) tidak nyaman didiagnosis HIV/AIDS, 5) kebutuhan dukungan dari keluarga dan teman, 6) koping, dan 7) harapan memiliki anak yang sehat. Penelitian ini dapat bermanfaat dalam pengelolaan dan memahami stres yang dialami perempuan hamil yang didiagnosis HIV/AIDS, sehingga asuhan keperawatan yang diberikan efektif dan optimal. Implikasi penelitian ini berupa informasi bagi pemerintah dan perawat yang bekerja di area keperawatan maternitas tentang kebijakan pengelolaan HIV/AIDS bagi perempuan hamil.
\end{abstract}

Kata kunci: grounded theory, HIV/AIDS, koping, perempuan hamil, stres

Abstract

This qualitative research identified stress and coping mechanism on pregnant women who were diagnosed HIV/AIDS using grounded theory approach. There were six participants involved in the study. Data were collected using in-depth interview, observation, and literature review. Seven themes were found: 1) being worry on the safety of the fetus, 2) being treated differently from other pregnant women, 3) the expensive treatment 4) the discomfort being diagnosed HIV/AIDS, 5) the need offamily's and friends'support, 6) coping mechanism, and 7) the expectation to have healthy children. This study can provide information to the decision maker and the nurses who work in the area maternity nursing care in managing pregnant women with HIV/AIDS.

Key words: grounded theory, HIV/AIDS, pregnant women, stress coping

\section{LATAR BELAKANG}

Acquired Immunodeficiency Syndrome (AIDS) merupakan masalah kesehatan dunia pada saat ini maupun masa yang akan datang karena penyakit ini menyebar hampir di seluruh negara. Masalah AIDS cukup mendapat perhatian di Indonesia karena Indonesia adalah negara berkembang yang memiliki peningkatan kasus AIDS dari tahun ke tahun. Data Departemen Kesehatan (2007) menunjukkan jumlah kasus HIV/AIDS sampai Desember 2006 sebanyak 3859 orang (986 kasus HIV dan 2873 kasus AIDS). Sumber yang sama menyebutkan bahwa Jakarta mempunyai jumlah penderita AIDS tertinggi yaitu sebanyak 2565 kasus, serta kematian tertinggi karena AIDS sebanyak 420 kasus.

Data Rumah Sakit Umum Pusat Nasional Cipto Mangunkusumo Jakarta menunjukkan peningkatan yang signifikan jumlah bayi yang dilahirkan dari ibu HIV positif dari tahun 1996 sampai dengan 2005. Pada tahun 1996 dan 2002 diketahui masingmasing terdapat 1 kasus bayi yang lahir dari ibu HIV positif, sedangkan pada tahun 2003 diketahui terdapat 17 kasus baru. Jumlah ini meningkat dua kali lipat menjadi 44 kasus pada tahun 2004 dan terdapat 74 kasus baru pada tahun 2005. Dari total 118 kasus tahun 1996 dan 88 kasus pada tahun 2005, sebanyak 88 bayi/ anak diketahui mengalami HIV positif dari hasil tes darahnya (Habsyi, 2007). 
Pencegahan penularan HIV dari ibu ke bayi merupakan prioritas strategi penanggulangan AIDS Nasional 2003-2007. Intervensi PMTCT (Prevention of Mother to Child HIV Transmission) yang dilakukan adalah minum obat Antiretroviral (ARV) profilaksis selama hamil, persalinan dengan seksio sesarea berencana, serta pemberian susu formula, sehingga risiko penularan dapat ditekan dari 25-45\% menjadi 2\% (Depkes RI, 2005).

Ibu yang menderita HIV positif sangat berisiko menularkan kepada bayinya yang tidak hanya berdampak pada masalah fisik tetapi juga psikologis dan sosial. Didiagnosis HIV/AIDS merupakan suatu ancaman yang besar pada perempuan hamil seperti ancaman terhadap infeksi dalam hidupnya, bayi, dan keluarga (Kennedy, 2003). Dampak psikologis perempuan HIV/AIDS akan mengalami depresi prenatal (Blanney et al., 2004). Stigma dan diskriminasi baik dari keluarga, masyarakat serta tenaga kesehatan juga masih ada (Fortinash \& Worret, 2004). Oleh sebab itu, peran perawat maternitas adalah memberikan pelayanan keperawatan, memberikan dukungan psikologis, serta menggali potensi yang ada pada perempuan tersebut sehingga dapat menggunakan koping yang adaptif untuk menghadapi stressor.

Kenneth, Pakenham, dan Rinaldis (2001) dalam penelitiannya menyatakan sumber koping perempuan hamil HIV positif ada dua yaitu internal berupa optimisme dan eksternal berupa ketersediaan dukungan sosial. Hawari (2006) menyatakan bahwa sumber koping seseorang tidak hanya tergantung pada dukungan sosial tapi juga kepercayaan agama yang dianut.

Data banyaknya kasus HIV/AIDS serta dampak yang ditimbulkannya pada perempuan hamil menunjukkan perlunya digali secara mendalam mengenai berbagai penghayatan berupa stres perempuan hamil yang didiagnosis HIV/AIDS serta mendapatkan informasi secara detail dan jelas tentang berbagai upaya untuk menanggulangi permasalahan. Tujuan dari penelitian ini adalah ditemukannya stres dan koping perempuan hamil yang didiagnosis HIV/AIDS di DKI Jakarta.

\section{METODE PENELITIAN}

Penelitian menggunakan pendekatan grounded theory. Subjek dalam penelitian ini adalah perempuan hamil yang didiagnosis HIV/AIDS yang berdomisili dan melakukan pengobatan di DKI Jakarta. Pengambilan sampel secara purposif didapatkan enam orang yang berpartisipasi dan data telah mencapai saturasi. Pengambilan sampel dilakukan di Poliklinik Kebidanan dan Penyakit Kandungan sebuah rumah sakit di Jakarta.

Peneliti menyakinkan bahwa partisipan terlindungi dengan memperhatikan aspek kebebasan, menghormati hak-hak partisipan, prinsip confidentiality, anonimity, dan protection from discomfort. Tahapan analisis data adalah mengumpulkan seluruh data dari observasi partisipan, wawancara mendalam, catatan lapangan, jurnal, dan literatur. Pengkodean dilakukan pada tiga tingkatan (level) yaitu: level I: kata-kata kunci, level II: pembentukan kategori-kategori dan level III: pembentukan tema (Streubert \& Carpenter, 1999). Proses analisis dilanjutkan dengan pengembangan konsep, pembentukan variabel inti, pembentukan teori hasil penelitian atau grounded theory.

\section{HASIL PENELITIAN}

Usia partisipan dalam penelitian ini bervariasi antara 22 sampai 27 tahun. Pendidikan partisipan adalah satu orang berpendidikan PGSD dan lima orang lainnya berpendidikan SMU. Semua bekerja sebagai ibu rumah tangga. Lima partisipan beragama Islam dan satu orang Kristen. Dua orang partisipan hamil anak pertama dan dua orang hamil anak yang ke dua, selebihnya hamil anak yang ketiga. Usia kehamilan berkisar antara 11 minggu-34 minggu gestasi. Waktu didiagnosis HIV positif bervariasi antara 1 minggu sampai satu tahun. Empat orang partisipan mengaku tidak pernah mengkonsumsi narkoba, seks bebas. Dua orang lainnya pernah mengkonsumsi narkoba serta melakukan hubungan seksual dengan lebih dari satu orang. Empat partisipan berdomisili di DKI Jakarta dan 2 orang lainnya di luar DKI Jakarta. 
Hasil penelitian menemukan tujuh tema utama yang memaparkan stres dan koping partisipan yang menjalani kehamilan didiagnosis HIV/AIDS, diantaranya:

\section{Khawatir terhadap keselamatan janin}

Seluruh partisipan secara ringkas mengekspresikan pengalamannya dengan jawaban yang sama bahwa mereka sangat mengkhawatirkan keadaan janinnya apakah kemungkinan tertular HIV? Partisipan mengungkapkan rasa takut apabila janin mereka mengalami kecacatan fisik setelah lahir seperti anggota badan yang tidak lengkap seperti ungkapan berikut:

"...saya tuh takut mbak kalau anak saya "napa-napa nya, tertular atau cacat atau gimananya..." (P 1)

Kekhawatiran yang dialami oleh partisipan terhadap keselamatan janin terlihat dari perilaku saat partisipan menceritakan mengenai kehamilannya, ekspresi wajah terlihat cemas, terlihat kebingungan, ketakutan sambil mengelus-ngelus perutnya. Saat periksa hamil partisipan juga aktif menanyakan tentang keadaan janinnya terutama kemungkinan mereka dapat menularkan pada janinnya atau janin mereka akan cacat kepada dokter.

\section{Diperlakukan berbeda dari ibu hamil lainnya}

Beberapa perbedaan yang dirasakan oleh partisipan adalah: Penatalaksanaan pengobatan khusus yang mereka terima tidak seperti ibu hamil lainnya yaitu harus melahirkan dengan sectio sesarea, meminum obat ARV, tidak boleh memberikan ASI yang diganti dengan susu formula. Seluruh partisipan menjelaskan bahwa penatalaksanaan pengobatan yang mereka terima merupakan salah satu upaya untuk meminimalkan penularan HIV dari Ibu ke janin, seperti yang diungkapkan:

“...aku harus lahir sesar supaya anaknya gak ketular, ini juga gak boleh ngasihin ASI, dikasih susu formula, katanya kalau saya tidak menyusui 2\% tidak menularkan ke anak... .Saya kan dapat dua obat, satu neviral dan yang satunya lagi reviral, minumnya $1 x 1$ dan $2 x 1$, obatnya buat 2 minggu dikasih, kata dokternya obatnya buat nekan virus supaya jangan naik gitu." (P 2)

Tiga dari enam orang partisipan dalam penelitian ini menyatakan bahwa perbedaan yang dirasakan dari perempuan hamil lainnya adalah dengan tulisan SIDA (penderita HIV/AIDS) pada status mereka, ungkapan yang kurang menyenangkan dari tenaga kesehatan, seperti yang diungkapkan dibawah ini:

“...bidannya bilang, "oh, kamu yang SIDA itu 'kan, nanti kamu yang terakhir, karena kamu penyakitnya lain” dengan ketus dia jelasin ke saya." (P 1)

Perlakuan berbeda dari ibu hamil lainnya juga tergambar dari perilaku partisipan. Saat melakukan pemeriksaan kehamilan, mereka lebih senang duduk menyendiri dan terlihat sedih. Dari hasil observasi ditemukan bahwa para partisipan biasanya mendapat giliran terakhir setiap akan dilakukan pemeriksaan kehamilan. Peralatan dibedakan dengan perempuan hamil lainnya dan tenaga kesehatan saat melakukan periksa dalam memakai sarung tangan dua lapis. Mereka juga menerima ungkapan yang kurang menyenangkan dari tenaga kesehatan. Pada wajah partisipan terpancar rasa ketidakpuasan terhadap pelayanan yang mereka terima. Kadang partisipan harus bolak-balik masuk ke ruangan dan bertanya kepada petugas mengapa mereka belum dipanggil? Keluar dari ruangan dengan wajah terlihat kesal, duduk dengan menggerutu sendiri dan satu orang dari enam partisipan menangis karena merasa tidak puas dengan kenyataan yang ada. Partisipan empat menggunakan waktu menunggu giliran dipanggil untuk pemeriksaan dengan merokok di luar ruang tunggu.

\section{Banyak membutuhkan biaya pengobatan}

Empat dari enam partisipan dalam penelitian ini menyatakan bahwa mereka kesulitan dalam biaya pengobatan, seperti ungkapan berikut ini:

“...katanya lahiran aku operasi gitu, aku gak mau tau gimana caranya harus menyiapkan uang yang lebih...anaknya lahir juga butuh uang yang banyak, buat beli susu dan periksa dianya juga...aku gak mau pikirkan itu mbak, biarin aja R ama bundanya yang mikir biayanya gimana." (P2) 
Pernyataan membutuhkan biaya terlihat dari hasil observasi ketika partisipan melakukan pembayaran, setiap datang berobat membayar empat puluh ribu rupiah. Mereka juga harus membayar dengan jumlah yang sama apabila mereka berobat ke Kelompok Studi Khusus (Pokdisus). Partisipan juga menanyakan ke petugas perkiraan biaya yang mereka butuhkan untuk pengobatan dan persalinan. Tersirat rona kecemasan dan kesedihan setelah mendengar penjelasan mengenai biaya pengobatan yang harus mereka persiapkan.

\section{Tidak nyaman didiagnosis HIV/AIDS}

Dua orang partisipan (1 dan 6) mengungkapkan berbagai perasaannya ketika diri mereka tidak menerima kenyataan, perasaan takut, bayangan kematian, hidup tidak berarti, cobaan dari Allah, dan tidak menerima apa yang dialami karena belum banyak mengetahui informasi tentang HIV/ AIDS sehingga membuat partisipan bersedih. Mengungkapkan atau diketahui identitas diri mereka HIV positif oleh keluarga dan teman merupakan suatu ketakutan terbesar yang dirasakan oleh partisipan. Mereka berusaha untuk menutupi identitas mereka, baik pada keluarga maupun teman, seperti yang diungkapkan:

"Saya tidak terima, karena bayangan kematian gitu...jadi saya sangat stres, saya down,... nangis sejadi-jadinya...waktu itu sempat benci sih ama suami...kenapa saya kena, jangankan narkoba, merokok gak, keluar malam gak pernah, jadi perempuan nakal juga jauh dari bayangan, kok bisa kena penyakit begini. " (P1)

Partisipan menyatakan tidak nyaman saat didiagnosis HIV. Hal ini tergambar dari perilaku partisipan. Semua partisipan dalam penelitian ini menangis saat mengungkapkan rasa ketidaknyamanannya, bicara terbata-bata, kadang memukul-mukul dada sambil menghapus air mata. Satu partisipan mengungkapkan kemarahannya kepada suami di telepon dengan nada tinggi, mengepalkan tangan, memperlihatkan hasil laboratorium, terlihat sedih, gemetar saat mengisi biodata di Pokdisus dan mengelus dada. Ketakutan apabila diketahui oleh orang lain sebagai seorang penderita HIV positif terlihat dari perilakunya duduk di pinggir, menyendiri, menyimpan hasil laboratorium dalam tas, lebih banyak diam, dan berbicara pelan.

\section{Kebutuhan dukungan dari keluarga dan teman}

Seluruh partisipan membutuhkan dukungan baik dari keluarga maupun dari teman. Empat dari enam partisipan mengungkapkan bahwa mereka menerima dukungan dari keluarga dan teman, seperti ungkapannya:

“...saya pergi ke rumah sakit untuk cek laboratorium ke Pokdi, disana aku ketemu dan cerita-cerita dengan orang yang sama... keluarganya semua sudah tau, Bunda orangnya sabar banget." (P 2)

Sedangkan dua partisipan lainnya tidak mendapatkan dukungan dari keluarga, seperti ungkapan berikut ini:

“...justru dari keluarga suami sendiri (mertua, kakak) mereka ngucilin mulai dari piring, gelas, sisir, gunting kuku, sendok dipisah, padahal mereka sudah diberi tahu dokter, bahwa itu tidak menular, tetapi tetap aja di rumah dipisah....Aku protes sama ibu, saya bilang ke ibu, apa-apa sama keluarga sendiri dikucilin apalagi sama orang lain...kalau saya berada di rumah mertua...ya sadar diri aja, saya bawa air sendiri, saya makan dulu di rumah baru ke tempat mertua." (P 1)

Perilaku yang kurang mendukung dari keluarga ini terlihat dari sikap ibu mertua partisipan satu yang datang menjenguk anak dan menantunya di Rumah Sakit tersebut. Ibu mertua membawa makanan sendiri dari rumah, sisa dari makanan yang dia makan diberikan kepada anak dan menantu. Saat kunjungan rumah peneliti juga melihat dari sikap anggota keluarga yang lain dari partisipan tiga, bahwa mereka menyatakan ketakutan akan tertular dari partisipan sehingga mereka memutuskan untuk tidak membolehkan partisipan dan suaminya tinggal di rumah orangtua lagi.

\section{Koping}

\section{a. Koping adaptif}

Lima dari enam orang partisipan dalam 
penelitian ini melakukan kegiatan dan bersikap yang bertujuan untuk membuat diri mereka relaks diantaranya menonton TV, tidur, makan, berbicara dengan teman atau keluarga, bahkan dengan cara tidak mengingat-ingat kalau dirinya positif HIV. Partisipan berusaha melupakannya dan banyak beribadah. Pernyataan ini diungkapkan sebagai berikut:

"Saya sholat dan saya bersyukur tahu lebih awal ada kesempatan bertobat lebih awal dan merupakan teguran bagi saya karena selama ini saya sholatnya bolong-bolong... Allah kasih teguran ke saya kasih penyakit seperti ini, ada hikmah bagi saya supaya lebih dekat lagi ke Dia." (P1)

\section{b. Koping maladaptif}

Satu dari enam partisipan menyatakan bahwa saat pertama kali dinyatakan HIV positif oleh dokter ia menggunakan koping mal adaptif dengan mengkonsumsi narkoba. Ini diungkapkan dengan pernyataan berikut:

"Ya sempet juga sih kayak nangis, sedih, sedih gitu, ya...cuma paling nyenangin diri, ya paling nonton TV, kadang ngerokok gitu (ketawa), ngilangin stres mbak... hari pertama tau aku sempat kayaknya pengen make, pengen apa? Akhirnya aku nyimeng...narkoba...cuma sehari doang." (P4)

\section{Harapan memiliki anak yang sehat}

Kesehatan dan keselamatan anak merupakan prioritas utama partisipan dan sekaligus sebagai motivator bagi mereka. Harapan ini merupakan impian semua partisipan dan menjadikan mereka untuk bisa bertahan hidup, seperti ungkapan ini:

"Aku berusaha supaya anak gak kena aja, saya berdoa pengennya Tuhan kasih penyakit ke aku jangan ke anak...saya berusaha untuk benar dan dorongan dari anak juga...saya pengen lihat pertumbuhan dia, saya usahin sehatin badan aja deh. "( $(\mathrm{P} 4)$

\section{PEMBAHASAN}

Hasil penelitian ini menyatakan bahwa stressor pada perempuan hamil yang didiagnosis HIV/
AIDS adalah khawatir terhadap keselamatan janin, diperlakukan berbeda dengan ibu hamil lainnya, banyak membutuhkan biaya pengobatan, tidak nyaman didiagnosis HIV/AIDS. Stresor ini menimbulkan stres pada perempuan hamil tersebut sehingga mereka melakukan mekanisme koping yang bermacam-macam, umumnya mekanisme koping yang adaptif dan maladaptif.

Temuan ini sesuai dengan penelitian Kennedy (2003) yang menyatakan bahwa ibu hamil yang didiagnosis HIV/AIDS akan mengalami stres. Stres ini dapat menimbulkan ancaman yang besar pada perempuan hamil tersebut, diantaranya ancaman terhadap infeksi dalam hidupnya, bayi dan keluarganya. Dia akan kaget, depresi, cemas bahkan ada keinginan untuk bunuh diri. Reaksi ini muncul karena perempuan hamil memikirkan apa yang akan terjadi selanjutnya berkaitan dengan kesehatan dirinya dan kehamilan serta janin yang dikandungnya. Bahkan menurut penelitian Johnstone, et al., (1990 dalam Kennedy 2003), perempuan yang didiagnosis HIV reaksinya adalah mengakhiri kehamilan karena perempuan tertekan atau tetap mempertahankan kehamilan. Pilihan yang diambil tergantung dari apakah kehamilan tersebut diinginkan atau tidak, serta dukungan sosial yang bersifat positif.

Penelitian ini sesuai dengan temuan Dalmaida (2006). Sumber stres lainnya pada perempuan hamil HIV/AIDS adalah stigma dari lingkungan seperti pandangan negatif masyarakat terhadap orang dengan HIV/AIDS (ODHA). Mereka juga mengalami rasa bersalah, malu, atau distres emosional ketika menjelaskan status mereka sebagai seorang pengidap HIV kepada teman, anggota keluarga, pasangan, dan orang lain.

Stres lainnya adalah kesulitan dalam keuangan karena tidak mampu membayar biaya pengobatan, kesulitan memahami hidupnya (harus mematuhi pengobatan setiap hari serta harus mengurangi perilaku yang menularkan HIV), dan mengalami efek samping obat.

Temuan ini mendukung hasil penelitian yang dilakukan oleh Chan, et al. (2006) di Hongkong. 
Hasil penelitian Chan mengungkapkan bahwa faktor finansial merupakan salah satu sumber stres yang dialami oleh orang yang memiliki HIV positif. Biaya pengobatan yang sangat mahal, sulitnya mencari pekerjaan karena status ODHA, dan kebutuhan akan makanan bergizi tinggi merupakan situasi yang dapat menambah beban hidup ODHA.

Seluruh partisipan dalam penelitian ini memerlukan dukungan baik dari keluarga maupun teman. Hal ini sesuai dengan penelitian Kenneth, Pakenham, dan Rinaldis (2001) yang menyatakan sumber koping perempuan hamil HIV positif ada dua yaitu internal berupa optimisme dan eksternal berupa dukungan sosial. Penelitian lain menunjukkan bahwa perempuan hamil HIV mempunyai optimisme yang tinggi karena mereka mendapatkan dukungan sosial yang baik (Anderson et al., 1995; Reced et al., 1994; Taylor et al., 1993 ; Pakenham \& Rinaldis, 2001)

Kusniari (2004) menyatakan bahwa dukungan sosial (keluarga, teman, dan lingkungan) sangat diperlukan ODHA. Dukungan ini sangat diperlukan agar mereka tidak merasakan sendiri dalam menyelesaikan masalahnya dan masih ada orang yang peduli dengan nasibnya. Keluarga dan teman dapat memberikan motivasi agar mereka lebih optimis menjalani hidup ke depan.
Koping yang lain adalah berhubungan dengan spiritual dengan melakukan ibadah yang teratur supaya kepercayaan diri bertambah dan pandangan positif semakin berkembang. Dalmida (2006) menyatakan ODHA yang melakukan spiritual atau praktik keagamaan seperti sembahyang akan berpengaruh positif terhadap kesehatannya. Aktivitas spiritual dan keagamaan akan memberikan relaksasi pada sistem saraf pusat dan meningkatkan fungsi sistem imun. Sebagian besar partisipan dalam penelitian melakukan aktivitas spritual seperti berdo'a dan sholat. Partisipan menjelaskan manfaat aktivitas spiritual yang telah dilakukan seperti menemukan suatu ketenangan dan kenyamanan.

Penelitian ini menemukan bahwa motivator terbesar bagi para partisipan adalah anak yang sehat. Partisipan sangat berharap dan berupaya melakukan yang terbaik untuk janin.

Hal ini sesuai penelitian Barosso (2003) tentang pengalaman perempuan HIV positif yang menjadi ibu. Barosso menyatakan bahwa para ibu sangat peduli terhadap perawatan anaknya khususnya penyakit yang terjadi akibat HIV.

Satu orang partisipan menggunakan koping maladaptif seperti merokok dan narkoba. Hal ini sesuai dengan hasil penelitian yang dilakukan oleh Sikkema et al. (2003) pada 268 partisipan HIV

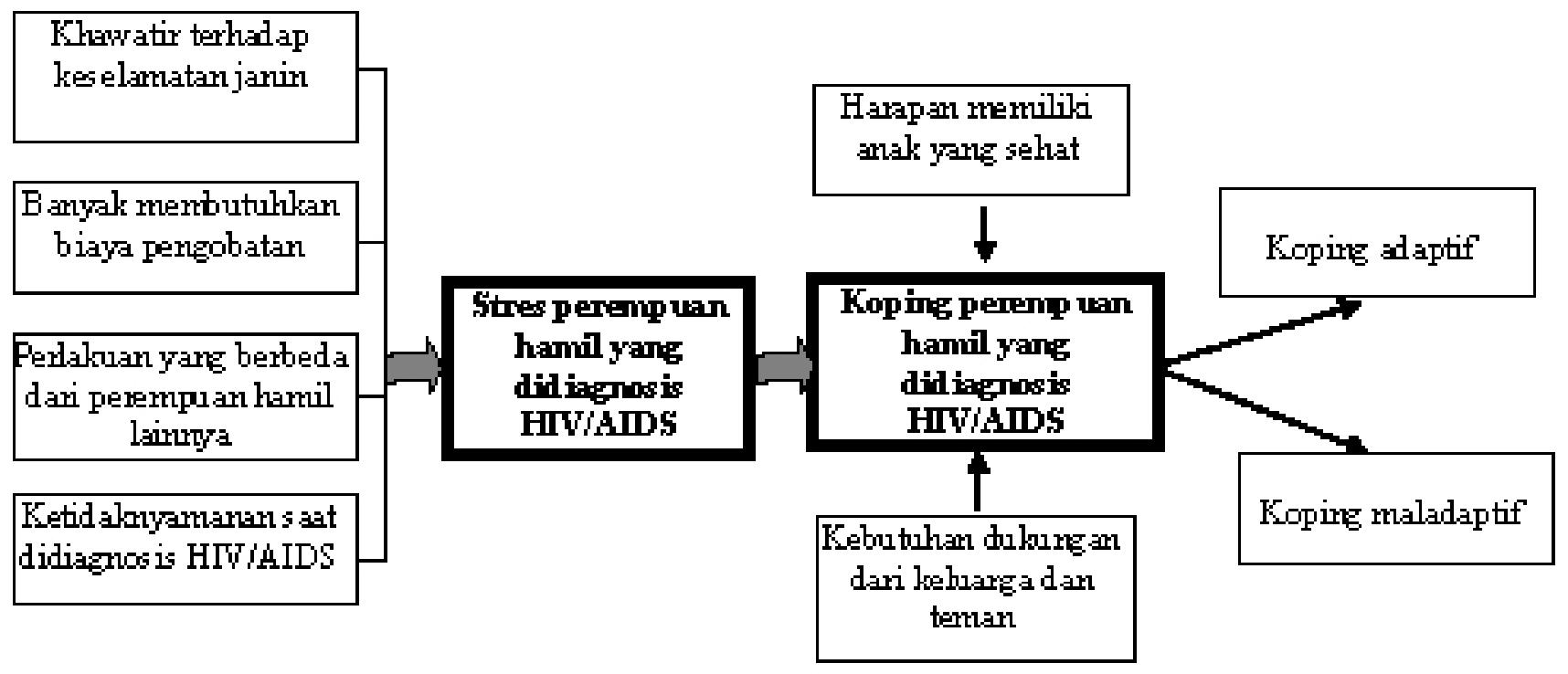

Stema l. Groun ded theory stres dan kopingperenpuan hamil yang didiagnosis HIV/AIDS diDKI Jakarta 
positif. ODHA yang mengalami kecemasan, depresi berat, dan kurang dukungan sosial menggunakan koping maladaptif seperti memakai narkotika misalnya marijuana, alkohol, dan merokok.

Skema 1 menjelaskan tentang kerangka konsep stres dan koping perempuan hamil yang didiagnosis HIV/AIDS. Perempuan hamil yang didiagnosis HIV positif mengalami berbagai stresor, baik yang berasal dari dirinya maupun janin yang dikandung. Perempuan hamil sangat mengkhawatirkan janin yang dikandungnya tertular atau mengalami kecacatan setelah lahir. Mereka juga mengalami perlakuan berbeda dari perempuan hamil lainnya, pengobatan yang berbeda, serta mendapat diskriminasi dari petugas kesehatan. Stresor lainnya adalah penatalaksanaan pengobatan yang mahal seperti melahirkan dengan seksio sesarea dan pemeriksaan laboratorium bagi diri dan bayinya. Selain itu, mereka juga merasakan ketidaknyamanan saat didiagnosis HIV positif.

Berbagai upaya telah dilakukan oleh partisipan untuk mengelola sumber koping dalam menghadapi masalah. Upaya tersebut adalah mereka membutuhkan dukungan dari keluarga dan teman, menggunakan koping adaptif dan maladaptif, serta harapan memiliki anak yang sehat.

\section{KESIMPULAN}

Sebanyak enam orang perempuan hamil yang didiagnosis HIV/AIDS berpartisipasi dalam penelitian ini. Beberapa stresor yang menyebabkan partisipan mengalami stres yaitu kekhawatiran terhadap keselamatan janin, menjadi berbeda hamil dengan HIV positif, banyak membutuhkan biaya, ketidaknyamanan didiagnosis HIV, dan kurangnya dukungan keluarga. Stresor nyata yang mempengaruhi bentuk koping adalah perlakuan yang berbeda dan lama waktu telah didiagnosis HIV/AIDS.

Para perempuan hamil yang didiagnosis HIV/ AIDS dalam penelitian ini telah melakukan berbagai cara dan upaya untuk mengelola stres diantaranya kebutuhan dukungan psikososial baik dari keluarga maupun dari teman. Semua partisipan mengharapkan anak yang dikandungnya sehat dan selamat dengan berupaya melakukan yang terbaik misalnya mengkonsumsi makanan yang bergizi tinggi dan obat ARV.

Hasil penelitian ini dapat menjadi data dasar bagi pemerintah dalam menanggulangi masalah HIV/AIDS, pencegahan bagi kelompok yang rentan tertular HIV/AIDS, dan pemberian sanksi hukum yang berat bagi pengguna narkoba terutama narkoba suntik. Asuhan keperawatan yang komprehensif dan komunikasi yang efektif sangat perlu dilakukan khususnya bagi klien perempuan hamil dengan HIV/AIDS. Penelitian selanjutnya dapat mengkaji tentang hubungan tingkat stres perempuan hamil yang didiagnosis HIV/AIDS dengan kejadian depresi postpartum (INR, MAW).

* Staf Akademik Kelompok Keilmuan Keperawatan Maternitas PSIK Universitas Riau

** Staf Akademik Kelompok Keilmuan Keperawatan Maternitas FIK UI

\section{KEPUSTAKAAN}

Barroso, S. M. (2003). Exploring the experience of motherhood among HIV-positive women. Research in Nursing \& Health, 26: 470482.

Blaney, N.T., et al. (2004). Psychosocial and behavioral correlates of depression among HIV-infected pregnant women. Journal AIDS Patient Care and STDs, 18 (7): 405-415.

Chan, et al. (2006). Illness-related factors, stress and coping strategies in relation to psychological distress in HIV-infected persons in Hongkong. AIDS Care, 18 (8): 997-982.

Dalmida, S.G. (2006). Spiritually, mental health, physical health and health-related quality of life among women with HIV/AIDS: Integrating spiritually into mental health care. Journal Issues in Mental Health Nursing, 27: 
185-198.

Departemen Kesehatan. (2005). Pedoman nasional pencegahan penularan HIV dari ibu ke bayi. Jakarta: Depkes RI. . (2007). Statistik kasus HIV/AIDS di Indonesia dilaporkan sampai dengan Desember 2006. Jakarta: Depkes RI.

Fortinash, K.M. \& Worret, P.A.H. (2004). Psychiatric mental health nursing. (3rd edition). Philadelphia: Mosby.

Habsyi, H. (2007). Program pencegahan penularan HIV dari Ibu ke bayi (PMTCT). Majalah SUPPORT, 70, 4-5. Jakarta: Yayasan Pelita Ilmu.

Hawari, D.H. (2006). Global effect HIV/ AIDS dimensi psikoreligi. Jakarta: Balai Penerbit FK UI.

Kennedy, J. (2003). HIV in pregnancy and childbirth. London: Elsevier Science.

Pakenham, K. I. \& Rinaldis, M. (2001). The role of illness, resources, appraisal and coping strategies in adjustment to HIV/AIDS: the direct and buffering effects. Journal of
Behavioral Medicine, 24 (3): 259-279.

Kusniari. (2004). Pelayanan HIV/AIDS berbasis komunitas. Makalah seminar, tidak dipublikasikan.

Sikkema, K.J., et al. (2003). AIDS-related grief and coping with loss among HIV positive men and women. Journal Behavioral of Medicine, 26 (2): 165-181.

Streubert, H.J. \& Carpenter, D.R.(1999). Qualitative research in nursing advancing the humanistic imperative. Philadelphia: Lippincott.

Perdamaian bukanlah berarti ketidakhadiran peperangan semata; Namun, ia adalah sebuah nilaisetonggak karakter kebaikan, kepercayaan, dan keadilan sejati.

(Baruch Spinoza)

Mereka yang berjiwa lemah tak akan mampu memberi seuntai maaf tulus.

Pemaaf sejati hanya melekat bagi mereka yang berjiwa tangguh.

(Mohandas Gandhi)

Menjadi dewasa berarti menghadapi, dan bukan menghindar, semua krisis yang datang.

(Fritz Kunkel)

Hidup adalah percobaan. Semakin banyak cobaan semakin baik.

(Ralph Waldo Emerson) 